\title{
Mining
}

\section{Comparative study of the main flotation frothers using a new HYDROMESS adapted technique}

\author{
Estudo comparativo dos principais espumantes \\ com o uso de uma nova técnica HYDROMESS
}

Moacir Medeiros Veras

Professor, M.Sc. Bolsista DTI3/CNPq - Projeto

Estruturante de C\&T Mineral-RN

Instituto Federal de Educação, Ciência e

Tecnologia do Amapá - Macapá - Brazil

moacir.veras@ifap.edu.br

Carlos Adolpho Magalhães Baltar

D.Sc., Universidade Federal de Pernambuco UFPE/CTG/DEMINAS

Rua Acadêmico Hélio Ramos, s/nº - Cidade Universitária. CEP 50740-530. Recife (PE).

camb@ufpe.br

\section{João Bosco de Araújo Paulo}

D.Sc., Universidade Federal do Rio Grande do Norte,

Centro de Tecnologia-DEQ-Campus Universitário, Natal (RN) - Brazil.

jbosco@eq.ufrn.br

José Yvan Pereira Leite

Prof., MSc., Coordenador - Projeto Estruturante de C\&T Mineral-RN

Instituto Federal de Educação, Ciência e Tecnologia do Rio Grande do Norte - Brazil. jyp.leite@ifrn.edu.br

\begin{abstract}
Stability of bubble size in the pulp zone and froth control is an important parameter for a successful flotation process. The present study compares the action of the main frothers in terms of: mean bubble size in the pulp zone, froth stability, surfacetension-lowering ability and reagent participation in flotation of a naturally bydrophobic mineral. Bubble size was determined using a new technique adapted from HYDROMESS, a device designed to measure drop size. The remaining indicators were obtained by determining surface tension and conducting flotation tests with the addition of hydrophobic (graphite) and hydrophilic (calcite) particles. The results indicate that methyl isobutyl carbinol (MIBC) is the most efficient frother in controlling coalescence, with critical coalescence concentration (CCC) reached at 20 ppm. Moreover, this frother has greater potential for selective action, since it increased calcite entrainment by only $2.3 \%$ at a concentration of $30 \mathrm{ppm}$. In flotation tests with a sample of graphite, MIBC produced higher recoveries.
\end{abstract}

Keywords: flotation, frother, froth control, coalescence, surface tension, froth stability.

\section{Resumo}

A estabilidade do tamanho das bolhas na zona de polpa e o controle da zona de espuma são passos importantes para o êxito de um processo de flotação. O estudo compara a ação dos principais espumantes com relação ao tamanho médio das bolhas na zona de polpa, à estabilidade da espuma, à capacidade de abaixamento da tensão superficial e à participação do reagente na flotação de um mineral naturalmente hidrofóbico. O tamanho das bolhas foi determinado com o uso de uma nova técnica adaptada com base no HYDROMESS, equipamento projetado para a medição do tamanho de gotas. Os demais indicadores foram obtidos por meio de determinação da tensão superficial e de testes de flotação com a adição de partículas hidrofóbicas (grafita) e hidrofílicas (calcita). Os resultados indicam que o metilisobutilcarbinol (MIBC) é o espumante mais eficiente no controle da coalescência, com a concentração crítica de coalescência (CCC) sendo atingida com 20 ppm. Além disso, possui maior potencial para uma ação seletiva, já que, numa concentração de 30 ppm, aumentou o arraste da calcita em apenas $2,3 \%$. Nos testes de flotação com uma amostra de grafita, o MIBC proporcionou as maiores recuperações.

Palavras-chaves: Flotação, espumante, controle da espuma, coalescência, tensão superficial, estabilidade da espuma. 


\section{Introduction}

Frothing has important functions in flotation, among which are: (1) to reduce surface tension of the liquid-gas interface to enable froth formation (Baltar, 2010); (2) hinder coalescence in order to stabilize bubble size (Grau et al., 2005) and (3) facilitate hydrophobic particle adhesion to air bubbles (Laskowski et al., 2003).

Frother reagents can be separated into two groups: ionic and neutral. Reagents from the first group are characterized by strong activity on solid surfaces

\section{Experimental}

\subsection{Material}

\section{Reagents}

Three frother reagents were used: (a) Methyl isobutyl carbinol (MIBC),

\section{Mineral Samples}

Highly pure mineral samples of graphite and calcite were used for the flo-

\section{Equipment}

(a) Hydromess system, composed of a photoelectric probe and glass capillary tubes with internal diameter of 0.8 $\mathrm{mm}$, used to measure bubble size;(b)

\subsection{Methodology}

\section{Determination of Bubble Size}

The Hydromess ${ }^{\circledR} 1.40$ system was used to determine mean bubble diameter. The device is equipped with data acquisition software and a photoelectric probe, composed of two luminous cells and two phototransmitters coupled to a glass capillary tube.

Constant-speed suction, produced and therefore unsuitable as flotation frothers. Neutral reagents, however, do not usually act on mineral surfaces, contributing to process selectivity (Baltar, 2010). Neutral frothers are characterized by a molecule in which the polar group is a hydroxyl $(-\mathrm{OH})$, generally in the form of alcohol or glycol. The most widely used types in flotation are: (1) methyl isobutyl carbinol (MIBC); (2) pine oil and (3) polyglycolic ethers.

Froth stability level depends, among other factors, on the type of frother used. Stable froths favor recovery, while unstable ones produce concentrates with higher grades. This study aims to determine the influence of the main frothers on bubble characteristics in the pulp zone and froth produced. Experimental results allow comparing the action of these frothers in terms of bubble size stability in the pulp zone, surface tension lowering, froth stability and increased recovery of naturally hydrophobic minerals. manufactured by CYTEC; (b) Pine oil, from Hercules Yarmor F and (c)
Glygolic ether - manufactured by Flomin Inc. tation tests. Vonder graphite and calcite from the Brejuí mine located in Currais
Novos (Rio Grande do Norte, Brazil) were used.
Modified Hallimond tube, 1 " diameter, equipped with porous plate $(10 \mu \mathrm{m})$, was used in flotation tests; (c) K100 Krüss tensiometer, used to measure surface tension of the solutions and (d) MALVERN Mastersizer 2000 Laser Particle Size Analyzer, used to characterize the graphite and calcite. at the end of the glass capillary tube, generates a collection of bubbles that pass through the probe (Figure 1). Luminous cell 1 , located at a distance "a" of $2 \mathrm{~mm}$ from luminous cell 2 , with an inclination of $90^{\circ}$ between them, emits light beams to phototransmitters aligned with the luminous cells. They detect the begin-

ning and end of the cylindrical ellipsoid (deformed bubble) inside the glass capillary tube, based on the refraction index of the phases.

The readings of captured bubbles are sent by electrical signal based on the difference between the refraction indices of the phases present.

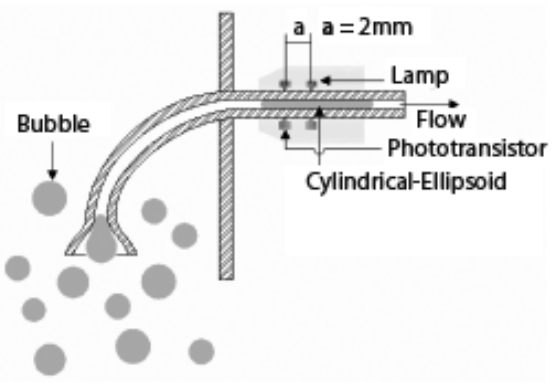

Figure 1

Photoelectric suction probe to capture air bubbles and cylindrical ellipsoid formation in the glass capillary tube (Paulo et al., 2003). 
The system is composed of a glass capillary tube, photoelectric probe, flotation column, escape valve to control suction speed of the aspirated bubbles, vacuum pump coupled to a Kitasako flask to generate a vacuum and bubble suction in the glass capillary tube immersed in the solution, porous plate aerator

Figure 2

Apparatus to determine mean bubble diameter using the Hydromess technique in a flotation column.

\section{Flotation Tests}

Flotation tests were conducted in a modified Hallimond tube, with a vacuum pump for aeration and a rotameter to control air flow, in addition to a kitazato flask connected to the vacuum pump

\section{Results and discussion}

\section{Surface tension lowering}

The frothing ability of a surfactant can be indirectly evaluated by determining surface tension. Higher surface tension lowering indicates

Table 1

Surface tension of each of the frother samples.

\section{Bubble size in the pulp zone}

The ability to avoid bubble coalescence was determined by mea-

Figure 3

Influence of frother concentration on mean bubble diameter. and rotameter to control air flow into the system, as illustrated in Figure 2.

Distilled water was used in the tests. Suction speed was adjusted to values of 1.5 $\mathrm{m} / \mathrm{s}$ with the aid of a vacuum pump and air flow was maintained constant at $122 \mathrm{~cm}^{3}$ / min for all assays.
The influence of frother concentration at the $0-50 \mathrm{ppm}$ range was determined. Next, $\mathrm{pH}$ was varied between 2 and 10, using a constant concentration of $10 \mathrm{ppm}$ for all assays. Hydrochloric acid $(\mathrm{HCl})$ and sodium hydroxide $(\mathrm{NaOH})$ were used to adjust $\mathrm{pH}$ levels. with a funnel to filter the floated mass. Operational conditions were kept constant during all flotation tests, as follows: air flow of $122 \mathrm{~cm}^{3} / \mathrm{min}$, distilled water with characteristic $\mathrm{pH}$ (around 5.8), condition- ing time and flotation time fixed at $1 \mathrm{~min}$ ute. Frother concentration ranged from 0 to $50 \mathrm{ppm}$. Floated material was filtered in a vacuum pump and then oven-dried at $85^{\circ} \mathrm{C}$ for later weighing. greater frothing intensity (Xia and Peng, 2007). Results obtained for the surface tension of pure reagents are presented in Table 1.
Results indicate that higher surface tension lowering was obtained with MIBC, suggesting greater frothing power for this surfactant.

\begin{tabular}{|c|c|}
\hline FOAMING & SURFACE TENSION, MN/M \\
\hline MIBC & 22.7 \\
\hline Pine oil & 30.2 \\
\hline Polyglycolic ether & 29.6 \\
\hline
\end{tabular}

suring mean bubble size as a function of the concentration of each of the frothers. Results are displayed in Figure 3.

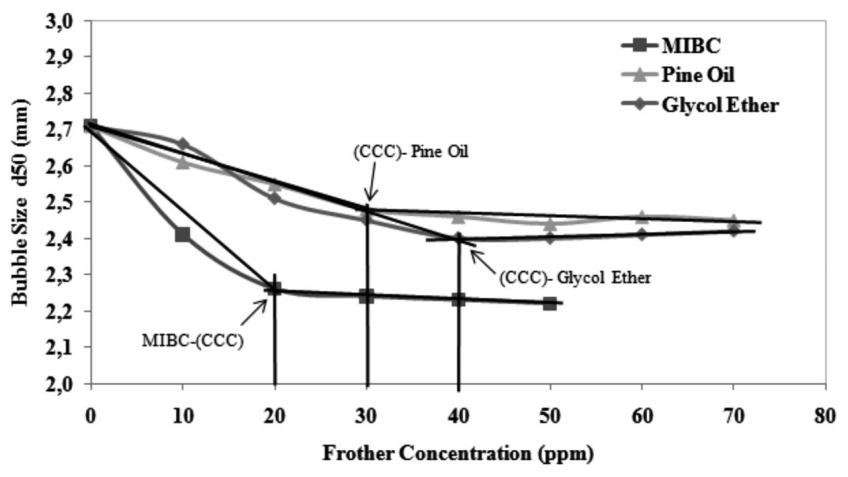


Results (Figure 3) show that the smallest bubble sizes were obtained with MIBC, indicating that this reagent is the most efficient in preventing coalescence. Critical coalescence concentration (CCC) for MIBC was found at a concentration of $20 \mathrm{ppm}$. At this concentration, minimum bubble size was stabilized at approximately $2.2 \mathrm{~mm}$. The reduction in mean bubble size is around 18\% when compared to mean diameter in the absence of frother. Cho and Laskowski (2002) observed bubbles with a mean size of $2.4 \mathrm{~mm}$ in the absence of frother. The CCC of MIBC was observed with approximately $8.0 \times 10-5$ mol.L-1, promoting a reduction in mean bubble size of around $28 \%$. The CCC of polyglycolic ether was observed at a concentration of around $40 \mathrm{ppm}$, with a minimum bubble size of $2.4 \mathrm{~mm}$, representing a reduction of $11 \%$ compared to mean bubble size in the absence of frother. Pine oil was the least able to prevent coalescence. The CCC was obtained at $30 \mathrm{ppm}$ of surfactant, with minimum bubble size of around $2.5 \mathrm{~mm}$, a $10 \%$ reduction in mean size compared to that obtained without frother. Szyszka et al. (2006) found CCC for pine oil at a concentration of $0.16 \mathrm{mmol} / \mathrm{dm} 3$, with bubble diameter corresponding to CCC of approximately $3.3 \mathrm{~mm}$, while Gupta et al. (2007) observed CCC of pine oil at around $10 \mathrm{ppm}$. Results are summarized in Table 2.

The results of the influence of $\mathrm{pH}$ on mean bubble size in the presence of each of the frothers are shown in Figure 4.

Results presented in Figure 4 confirm the greater ability of MIBC in preventing coalescence, given that bubbles in the presence of this frother exhibited the lowest sizes over the entire $\mathrm{pH}$ range tested. Mean sizes varied between 2.2 and $2.4 \mathrm{~mm}$, with the largest size observed near natural $\mathrm{pH}$.

Pine oil demonstrated the greatest sensitivity in terms of $\mathrm{pH}$ variation; it seems to be more efficient in preventing coalescence in acid medium. By contrast, glycol ether was the most resistant to $\mathrm{pH}$ variation, with a slight tendency to being more efficient in preventing coalescence in alkaline medium.

\begin{tabular}{|c|c|c|}
\hline FROTH & CCC (ppm) & MINIMUM BUBBLE SIZE $(\mathrm{mm})$ \\
\hline MIBC & 20 & 2.2 \\
\hline Polyglycolic Ether & 40 & 2.4 \\
\hline Pine Oil & 30 & 2.5 \\
\hline
\end{tabular}

Mean bubble size in the absence of frother: $2.7 \mathrm{~mm}$.

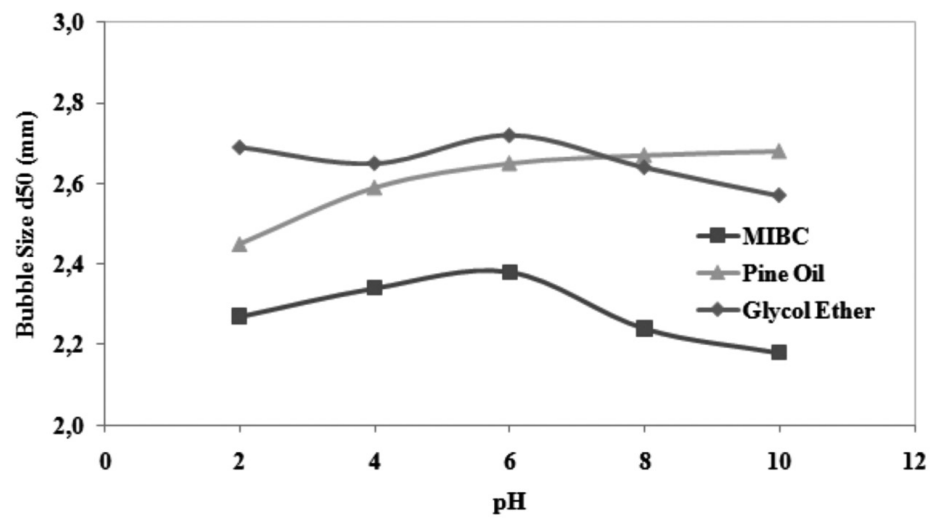

\section{Froth Stability}

Froth stability is an important parameter for flotation. Stable froths favor recovery, but hinder selectivity owing to higher mechanical entrainment of gangue particles.

Considering that calcite is a mineral with a hydrophilic surface, in the absence of collector it could only be present in froth though mechanical entrainment. These tests were conducted to quantify the entrainment of hydrophilic particles in froth.

\section{Froth Stability}

Flotation of hydrophobic minerals is usually conducted with the simple addition of frother. Flotation tests were car-
There is a direct relationship between froth stability and amount of fine particles entrained (Hu et al., 2009). The more stable the froth, the greater the amount of hydrophilic particles trapped between the bubbles and, consequently, the less selective the frother. Figure 5 shows the influence of frother concentration on calcite entrainment. Results suggest that the most stable froth is produced by EPG. As expected, entrainment ried out with a graphite sample in order to observe the collector action of the frothers on the flotation of naturally hydrophobic
Table 2

Ability of frothers to prevent bubble coalescence.
Figure 4

Variation in mean bubble size as a function of $\mathrm{pH}$ for the frothers studied.

increases with frother concentration. The percentage of "floated" calcite increased from around $2 \%$ to around $13 \%$ with only $30 \mathrm{ppm}$ of glycolic ether.

MIBC produced the most unstable froth, demonstrating more selective action. This result is in accordance with the literature (Baltar, 2010). Maximum entrainment of hydrophilic particles was around $5 \%$, with a concentration of 50 ppm of frother. minerals. The results are presented in Figure 6 . Around $65 \%$ of graphite floated without the addition of any surfactant. 
The addition of frother increased the float-

Figure 5

Influence of frother concentration on mechanical entrainment of calcite particles trapped in froth.

with the addition of $50 \mathrm{ppm}$ of frother. EPG

Figure 6

Influence of frother concentration on graphite flotation.

\section{Conclusions}

The results showed the performance of three frothers in terms of avoiding coalescence between bubbles, frothing ability, froth stability and flotation of naturally hydrophobic minerals.

MIBC has greater frothing power. Hydromess system technique can be used to measure bubble size in a two-phase system. The equipment proved to be efficient with respect to reliability of data reading and result reproducibility. MIBC was the most efficient in preventing coalescence between

ability. The best results were obtained with

MIBC, achieving nearly $100 \%$ recovery

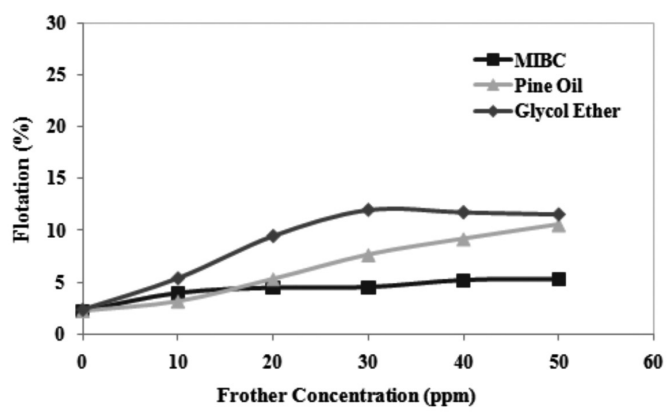

and MIBC obtained similar results, while the lowest recovery was observed for pine oil.

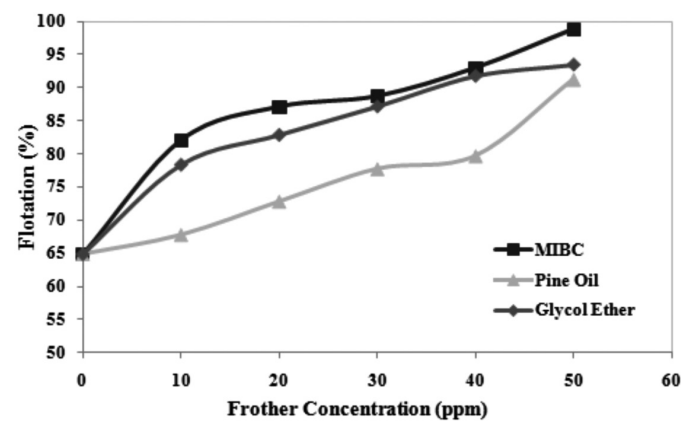

bubbles over the entire $\mathrm{pH}$ range tested. Critical coalescence concentration (CCC) was reached at a concentration of $20 \mathrm{ppm}$, with bubble diameter stabilizing at around $2.2 \mathrm{~mm}$, representing an $18 \%$ reduction compared to bubble sizes produced in a system with no additive. No significant differences were observed between polyglycolic ether and pine oil efficiency in preventing coalescence. However, pine oil is more sensitive to $\mathrm{pH}$ variation, functioning better in acid medium.
MIBC showed the highest selectivity potential. Around $5 \%$ of hydrophilic calcite particles were entrained with a concentration of $50 \mathrm{ppm}$. On the other hand, glycol ether promoted the highest entrainment, suggesting that this frother produce more stable froths. Flotation of naturally hydrophobic minerals showed greater efficiency than MIBC. The addition of $50 \mathrm{ppm}$ increased graphite recovery from $65 \%$ to approximately $99 \%$, while pine oil promoted the lowest increase in graphite recovery.

\section{Acknowledgement}

The authors thank the Brazilian Innovation Agency (FINEP) and the Foundation for Research Support of the State of Rio Grande do Norte (FAPERN) for funding the project (Fortalecimento da Estrutura de Apoio à Pesquisa para o Arranjo Produtivo Mineral do Rio Grande do Norte) and to National Council for Scientific and Technological Development (CNPq) for providing scholarships.

\section{References}

BALTAR, C.A.M. Flotação no tratamento de minérios. 2 ed. Recife: Editora Universitária da UFPE, 2010. 238 p.

CHO, Y.S., LASKOWSKI, J.S., Effect of flotation frothers on bubble size and foam stability. International Journal of Mineral Processing, 64, p. 69-80, 2002.

GRAU, R.A., LASKOWSKI, J.S., HEISKANEN, K. Effect of frothers on bubble size. IJMP, 76, p. 225-233, 2005.

GUPTA, A.K., BANERJEE, P.K., MISHRA, A., SATISH, P., PRADIP. Effect of alcohol and polyglycol ether frothers on foam stability, bubble size and coal flotation. International Journal of Mineral Processing, 82, p. 126-137, 2007. 
HU, S., OFORI, P., FIRTH, B. Monitoring of froth stability using electrical impedance spectroscopy. International Journal of Mineral Processing, 92, p. 15-21, 2009.

LASKOWSKI, J.S., TLHONE, T., WILLIAMS, P., DING, K. Fundamental properties of the polyoxypropylene alkyl ether flotation frothers. International Journal of Mineral Processing, 72, p. 289-299, 2003.

PAULO, J. B., FERNANDES Jr., W. E., MORAES, N. A., SOUZA, E. M., LIRA, B. B. Medida de tamanho e distribuição de gotas em novo design de extrator líquidolíquido. Sociedade Brasileira de Metrologia (SBM), 2003.

SZYSZKA, D., DRZYMALA, J., LUCZYNSKI, J., WILK, K. A., PATKOWSKI, J. Concentration of alfa-terpineol and (2-dodecanoyloxyethyl) trimethyl ammonium bromide required for prevention of air bubble coalescence in aqueous solutions. 40, p. 53-59, 2006.

XIA, Y.K., PENG, F.F. Selection of frothers from residual organic reagents for coppermolybdenite sulfide flotation. Internationa.l Journal of Mineral Processing, 83, p. 68-75, 2007.

Artigo recebido em 24 de agosto de 2012. Aprovado em 25 de setembro de 2013. 